\title{
STRUCTURAL CLASS III SUFFIXAL TYPE VERBATES IN SOUTHWESTERN DIALECTS OF UKRAINIAN LANGUGE: SEMANTIC AND ACCENTUATION SPECIFICS
}

\section{Ivanochko K. M.}

\section{INTRODUCTION}

During recent decades there actualize scholarly investigations of the roots of the Ukrainian nation, of the language as the base of its spiritual existence in particular. Studies of the Ukrainian language, of its living folk base cannot develop and be saturated with facts without detailed characteristics of its dialects.

Researches on Slavic dialects in the second half of the 20-th century are distinguished by their especial dynamics, which is associated with a significant change in the structure of knowledge of individual dialects and holistic continuums; with a considerable increase in the volume of information on dialects, the growth of linguistic information sources range and the improvement of material analysis means ${ }^{1}$.

An integral component of a dialect language is its accentuation sublevel. The accenteme as its basic unit, despite its suprasegment nature ${ }^{2}$, penetrates through the linguistic system. The accent system of dialects has its own specificity, in which archaic phenomena of different historical periods and innovative processes caused by lingual (phonetic, lexicalsemantic and semantic-grammatical) and extra-lingual (integration processes, reliefs) factors are interwoven ${ }^{3}$. They (accentuation features) make one of the important links that unites the past and the present, and printed accent markers, according to I. Ogienko, serve as a "strong and expressive method of determining the place of publication of old printed books", as well as "the nationality of handwritten accent artifacts", and

1 Гриценко П.Е. Феномен диалектного явления: онтология и гносеология. Исследования по славянской диалектологии: Судьба славянских диалектов и перспективы славянской диалектологии в XXI веке. № 17. Москва. 2015. Р. 9.

${ }^{2}$ Винницький В. М. Українська акцентна система: становлення, розвиток. Львів. 2002. P. 16.

${ }^{3}$ Попова Т. В. «Восточнословянские изоглоссы» и проблема дифференциации восточнославянского диалектного континуума. Исследования по славянской диалектологии: 8. Восточнославянская диалектология, лингогеография и славянский контекст. Москва. 2002. Р. 24. 
equally as "the nationality of old images, if they have accented inscriptions"4. Having analyzed the accentuation features of the Ukrainian artifacts he concluded that in terms of stress they were very close to the lively vernacular, especially to its western dialects ${ }^{5}$. To the stress specifics of the artifacts under study, he referred root stress predominance.

However, years of studying the accentuation system of verbs in the southwestern dialects of the Ukrainian language do not prove such opinionatedness of the scholar's conclusions, and that served as a motivating factor for choosing the research subject.

In the system of the language a special place is given to the verb as a lexical-grammatical class of words which is characterized by the unity of lexical-semantic, semantic-grammatical, phonetic, derivational and accentuation features, representing the richness of "grammatical categories and their subordinate grammatical meanings, in which the multifacetedness of objective reality processes is generalized"6. In the course of the historical development of the language despite the etymological difference of their word forms the components of the grammatical paradigm of verbs acquired the generalized morphological semantics, being accompanied by phonetic, morphological, grammatical and accent changes.

In the morphological structure of verbs of the Ukrainian language southwestern dialects there are derivatives of twelve structural classes, the components of which are etymologically rooted in the Proto-Slavic linguistic community and represent different degrees of dialect usage range, productiveness / non-productiveness of derivational nests, lexicalsemantic, semantic-grammatical, derivational, phonetic and accent features that reflect different historical periods of the language functioning. Most of them have already been the subject of the author's accentuation studies. It has been generalized that they are characterized by their belonging to different accent types (root, suffix-root, suffix-flexion), which derive from late-Slavic accent paradigms (baritone, oxytonic, and moving). The accentuation features of the dialect verbates of Structural Class III suffixal accent type have not been the subject of scholarly reflection yet. verbs.

${ }^{4}$ Огієнко І. Наголос, яко метод означення місця наголосу стародрукованих книжок. Замітки з історії наголосу на послугах палеотипії. Записки НТШ. Праці фільольогічної секиії. Львів. 1925. Vol. CXXXVI-CXXXVII. P. 221.

${ }^{5}$ Огієнко I. Наголос, яко метод означення місця наголосу стародрукованих книжок. Замітки з історії наголосу на послугах палеотипії. Записки НТШ. Праці фільольогічної секиї. CXXXVI-CXXXVII. Львів. 1925. Р. 224.

6 Ковалик I. I. Граматична структура системи дієслівних форм у сучасній українській літературній мові. Питання украӥнського $і$ слов'янського мовознавства. Вибрані праці. Львів - Івано-Франківськ. Рart II.. 2008. P. 148. 


\section{Lingual peculiarities of Structural Class III}

In the southwestern supradialect Structural Class III verbs are distinguished by high degree of usage productiveness. They represent the width of usage range, root, suffix and (not as frequent) variance accentuation. Some of the root accent type derivates (onomatopes ${ }^{7}$ and interjectives) have already been analysed. Drawing on longstanding studies in the field of Ukrainian dialectology, J. Zakrevskaya, following I. Ogienko, states that in the southwestern dialects (with rootedness into late Proto-Slavic Baritone Accent Paradigm III $^{8}$ ) throughout the whole verb paradigm the root accent is rather stable and does not succumb to any unification from the normative accent ${ }^{9}$.

In the structure of suffix accent type the verbs of the defined structure are distinguished by the highest degree of usage productiveness (hundreds of units). On language levels and sublevels they are characterized as follows:

- phonetic - three and four syllabic wordforms;

- morphological - preserving stem class suffix $-\boldsymbol{a}-(-\boldsymbol{x}$-) in the whole grammatical paradigm (with it being complete), the tendency to presence flexions variance in singular, despite their narrowing, caused by relational suffix $-j-$ reduction (with predominance in Boyko, Lemko and Transcarpathian subdialects, Upper Sannyan, partially in Upper Dniesterian ones), followed by shifting the stress to the root morpheme, which correlates with Serbo-Croatian accentuation features;

- semantic-grammatical - by the prevalence of iterative semantics (with the predominance of imperfective aspect grammeme in non-prefix formations), ability of semantic correlation with one-root derivates of aspect semantics;

- lexico-semantic - by correlation with one-root derivates of action types semantics;

${ }^{7}$ Іваночко К. Акцентуація фауноономатопоетичних дієслівних дериватів у південно-західних говорах української мови. Лінгвістика. Збірник наукових пращь. Луганськ. 2012. Випуск. 2 (26). Р.71 - 88; Іваночко К. Акцентуація ономатоепічних ентомологічних суфіксальних дієслівних утворень у південно-західних говорах української мови. Вісник Львівського університету. Філологія. Львів. 2012. Випуск 57. Р. 263 - 274; Іваночко К. М. Наголосова варіантність предметних ономатопів третього структурного класу в південно-західних говорах української мови. Науковий вісник Міжнародного гуманітарного університету. Серія: Філологія. Збірник наукових праџь. Одеса. 2017. Випуск 28. Р. 15 - 20.

${ }^{8}$ Скляренко В.Г. Історія українського наголосу. Дієслово. Київ. 2017. Р. 344.

9 Закревська Я. В. Система особових форм дієслова в західних говорах української мови (Теперішній час). Українська лінгвістична географія. Київ. 1966. Р. 132. 
- derivational - by ability to form prefix derivates (with imperfective aspect grammeme predominating), as well as sporadicity of some semes acquiring homonymic relations;

- ethymological - by rootedness into Proto-Slavic language community.

From the lexico-semantic view side they are characterized by the procedurality of the semantics of:

- wish (бazámu, верта́mu);

- influence on the object (subject(бодámu, виха́mu, горmámu, drcl'áti, касámu, мomámu i мómamu (< *motàti *motàjetb (2-nd baritone accent paradigm) (Скл., 346); перемута́mu; оберта́mu, пущаámu, пxámu, страхámu, str'il'áti, сягámu, тручámu;

- movement (ганя́mu, гуля́mu, літа́mu, минámu; приступа́йуm, руша́ти, тікати, тяга́mu);

- position changing (кляка́mu, кружс́́mu, лягámu, сідámu);

- request and enforcement (піхати, упраша́тися; запрічámu);

- speaking (вола́mu, галаса́mu);

- will expression (кичámu; proczczaty);

- being in a certain state (woniaty) and others.

To lexico-semantic features we also include preserved from ProtoSlavic times their ability to combine with one-root derivates of corresponding structural classes: VII (багámu / багнути, верта́mu / верну́ти, горта́ти / горну́ти, гуля́ти / гульнути, каса́ти / касну́ти, кляка́ти / клякну́ти, мина́ти / минути; мота́mu i мómamu / мотнути, обертати / обернути, піхати / пихнути, сяга́ти / сягну́ти, тяга́mu / тягну́ти), VIII (бода́ти / бости́, ляга́ти / лягти́ (лячú), IX (блука́ти / блуди́ти, ганя́ти / гони́ти, кружа́ти / кружи́ти, cmpaxámu / стра́mumu), XI (ліmámu / леті́mu, cidámu / сидіmu).

A number of the verbs with the semantics of movement and position change, as well as influencing a subject (object), are distinguished by their aspect relations correlation with one-root Structural Class VII (less frequent VIII and IX) verbs: верта́ти / верну́ти, гуля́ти / гульнути, каса́ти / касну́ти, кляка́ти / клякну́ти, мина́ти / минутми; мómaтu / мотнути, обертати / обернути, піхати) / пихнути, сяга́ти / сягнути; drcol'áti / дру́лити; кінча́ти / кі́нчити; пуща́ти / пусти́ти; руша́тu / руши́тu, сідámu / cícmu, str'il'áti / стрілити, приступа́йуm / nриступити. Verbates with the semantics of state, as well as that of verbalization processes, represent the inability of correlation (at low usage productiveness) with derivates of action types and aspects: буя́ти, woniaty, вола́mu, zаласа́mu. 
In the aspect of accent they are differentiated by the predominance of stem class suffix accent, which proved their rootedness into late ProtoSlavic accent paradigms as follows:

- (mainly) 2-nd baritone: бazámu (<*bøgàti *bøgàjetb (2-nd a.p.a.) (Скл., 346), верmámu (<*vertàti *vertàjetb (2-nd a.p.а.) (Скл., 346), woniaty (< *von'àti* von'àjetb (2-nd a.p.a.) (Скл., 186), zаня́mu (<*gān'àti *gān'àjetb (2-nd .a.p.a.) (Скл., 346), гуля́mu (< *gūl'àti *gūl'àjetb (2-nd a.p.а.) (Скл., 346), лimámu (< *lếtàti *lěttàjtb (2-nd a.p.а.) (Скл., 346), nixamu (<*pьxàti *pbxàtjetb (2-nd a.p.а.) (Скл., 186), str'il'áti (<*strēl'àti *strēl'àjetb (2-nd a.p.а.) (Скл., 346), npисmynáŭym (< *st̄̄pàti *stōpàjetb (2-nd a.p.a.) (Скл., 346);

- (rarely) 1-st baritone (кacámu < *k'asati *k'asajetb (1-st a.p.a.) (Скл., 346) and oxytonic (сягámu <*sẹgàti *sẹžete (a.p.b.) (Скл., 234).

With low degree of reconstruction in the process verbates of the dialects under investigation, as well as the Ukrainian language in general, Proto-Slavic accent paradigms, by the analogy to the second baritone accent paradigm, absolute majority of them proves accent uniformity (sequence of preserving suffix accentuation in the whole grammatical paradigm).

\section{Morphological and accentuational variance of oxytonic accent paradigm verbates}

In the dialect space under investigation distinguished is a group of polysemantic procedural verbates with semantics of influence on an object, which are characterized by the stem class suffix $\boldsymbol{- a}-$, grammeme iterativity and polisemantics. Lexico-semantic variants of these verbs in the course of historical development of the language have acquired the semantics of grammatical redundancy, the derivational marker of which is the variance of the grammatical paradigm (presence forms belonging to Structural Classes III and V) and the variance of their accent types (suffixe-root and suffix), (mostly) rooted in oxytonic accent paradigm with stressing the thematic affix in the Infinitive and the root - in the Presence: кремса́mu (кремса́ю, кремса́єш, кремса́є і кре́мшу, кре́мшеш, кре́мше); купа́ти (купа́ю, купа́єш, купа́є і кýnлюся, ку́плешся, кýnлеться) < *kōpàti *kópjetb (oxytonic accent paradigm) (Скл., 234), ламámu (ламáю, ламаєш, лама́є і ла́млю, ла́млеш, ла́мле) < *lāmàti *lámjetb (oxytonic

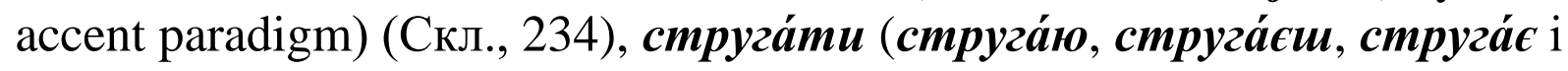
стру́жу, стружеш, стру́же) < *strøgàti *strúžetb (oxytonic accent paradigm) (Скл., 234), сука́mи (сука́ю, сука́єи, сука́є і су́чу, су́чеш, cýue) < *sūkàti *súčetb (oxytonic accent paradigm.) (Скл., 234), плека́ти (плека́ю, пле́каєш, пле́кає і пле́чу, пле́чеш, пле́че). 
Deriving from Proto-Slavic the verbate кремсати, despite its low usage productiveness in West and South Slavic languages, in the supradialect under analysis represents the width of dialectal range (Hutsul, Bukovynian and modern central Boyko subdialects), being marked by incompleteness of its grammatical paradigm.

In Hutsul subdialects it belongs to Structural Class III and is characterized by lexical-semantic derivation productiveness and accentuation (suffix and root) variance: kremsaty «обтісувати, обтинати галузки із зрубаного дерева» (Ziel) (SH, 107), кремса́ти «те саме, щзо крецкотіти»; обрубувати тонкі сучки сокирою»; перен. «тікати» (СГГ, 104) і кре́мсати «обрубувати гілки (сокирою)» (МСГГ, 86).

In Bukovynian subdialects the verb under analysis correlates with derivates of Structural Class III and has incomplete grammatical paradigm and suffix accent type: кремса́mu «бити» (СБГГ, 232).

In modern central Boyko subdialects the defined derivate shows suffixroot accent (with the grammatical paradigm of Structural Class V verbs): кремса́ти, кре́мшу, кре́мшеш «бити, лупџювати»; «дуже сварити»; «швидко виконувати важку фізичну роботу (переважно вирубувати ліс)»; «колоти з поспіхом дрова» (СГЦБ, 239 - 240).

Variance stress in the Galician variant of the Ukrainian literary language is the reflexion of stress peculiarities in the supradialect under research: кре́мса́mи «розрубувати», кремену́ти «різко виконати дію» (Жел., 377).

In the southeastern variant of the Ukrainian literary language and the modern Ukrainian language the verbate under research is conventional with the grammatical paradigm of Structural Class III and root accentuation (without the influence of accent analogy to Russian, where it represents high degree of derivation nest productiveness and suffix accent type: комса́ла, dialect (from кто комсает), вкромса́ль, выкромсалъ, докромсаль, искромсаль, закромсаль, накромсаль «нарвати (ганчірок)», обкромсаль «оббігати (навкруг)», откромсаль «відрізати, відвалити (значну частину)», покромсаль «побити (трохи)», перекромсаль (все), прикромсаль «прикроїв (чогось)», прокромсаль «змарнував» (ранок), раскромсали «розбити, потовкти» (y дріб'язки) (Даль II, 198): кре́мсати, -саю, -сш «обрубувати, обтесувати»; figurative «погано, невміло щзось робити» (Гр. ІІ, 302); кре́мсати, -саю, -сш (Погр., 268, УЛВН, 296), кре́мсати, -саю, -сш, colloquial «грубо, нерівно розрізувати, рубати» (СУМ, IV, 334); кре́мса́mи «обрубувати, обтісувати сокирою (Ж.), цุюкати (сокирою), возитися 3 сокирою (коло чогось)» (Ме); - 
Byelorussian. крэ́мсаць «різати тупим ножем», Upper Sorbian krjemić «крушити, дробити», Slovenian krêmsati «рубати тупою сокирою»; Proto-Slavic kremiti <*(s)krem- «крушити, дробити», together with Ukr. крім, кро́ма, кромса́mи. (ЕСУМ, III, 84).

The verbate купати in the southwestern supradialect is characterized by the width of usage range (Upper Dniesterian, Hutsul, Bukovynian and Boyko subdialects), moderate degree of lexical-semantic derivation (with low productiveness of the derivational nest), grammatic paradigm variance, correlating with derivates of Structural Classes III and V, and thus by accentuation variance.

In the dialects of Bukovynian and Upper Dniesterian subgroup it represents (at the width of usage range) grammatical paradigm incompleteness, belonging to Structural Class III and suffix accentuation type: куnámu на шнурку́ «вести вепра на шнурку до ставка купати» (ГБ, 99), купа́тисє «купатися (про вепра)» (ГБ, 99), купа́ли сє «плавати (про гусей)» (ГБ, 168), купа́jутm «мити» (УГР(г.), 179), купа́ти «обливати дівчат водою у перший понеділок після великодня» (СБГГ, 241).

In Boyko subdialects it is distinguished by increasing the productiveness of lexical-semantic derivation, belonging to Structural Class V verb paradigm (at phonomorphological interchange of the final root consonant $-\boldsymbol{n}-/ \boldsymbol{- n} \boldsymbol{\pi}$-, conditioned by the assimilation of the Presence suffix $-j-)$ and suffix-root accent which derives from oxytonic accent paradigm: купа́тися, ку́плет'с'а, ку́nл'уm'(и')с'a, купли́с'i «купатися» (СБГ, I, 395), скупати «покропити водою» (СБГ, II, 228), kupáti, kúplu, -le «кynamu» (СКУТГ, 109).

The verbate under analysis in the variants of the literary language, and thus in modern Ukrainian, represents low productiveness of the derivation nest, convention with Structural Class III grammatical paradigm and suffix accent type: куnámu, -áю, -áєu (Жел., 389), куnámu, -áю, -сш «купати» (Гр. II, 326), купа́mu, -áю, -а́єш «занурювати у воду для миття, освіження тощуо» (СУМ, IV, 401), купа́тися, -а́юся, -а́єшся «занурюватися у воду для миття, освіження тощзо» (СУМ, IV, 401).

Thus, the grammatical and accent variance of the analysed verb in the supradialect under research distributes them between two subgroups of dialects (Bukovynian-Upper Dniesterian and Carpathian) correlating with its language features in East, West and South Slavic subgroups of languages. Structural Class III grammatical paradigm, as well as suffix accent type, correlate with the Belarussian and Russian languages, and Structural class V grammatic paradigm, as well as suffix-root accent correlate with West and South Slavic languages: кynámu «кynamu»; - 
Russian кynámb, Byelorussian кynáų, Old Rus кynamu, Polish kapać, Check koupati, Slovak kúpat', Upper Sorbian kupać, Lower Sorbian kupaś, Polabian kopăt, Bulgarian къnя, Macedonian кane, Serbo-Croatian кýnamu, Slovenian kópati, Church Slavonic кжпати «занурювати в воду, освіжати, омивати»; - Proto-Slavic kopati «сидіти навпочіпки», connected with *[čepčti] (ECУM, III, $145-146)$.

The iterate ламати in the supradialect under research proves the width of usage range (Upper Dniesterian, Hutsul, Boyko and modern local Maramures dialects), correlates with one-root derivate of Structural Class IX with single-vector procedural semantics (ломи́mu), and despite low productiveness of the derivation nest proves its grammatical and stress variance (suffix-root and suffix with the latter predominating), which derives from the oxytonic accent paradigm: (<* lämàti *lámjetb (baritone accent paradigm) (Скл., 174): лама́mи «ламати (калину)» (ГБ, 21), лома́ти «ламати» (ГБ, 233), лома́ла (ГБ, 208), лома́ў (ГБ, 208),

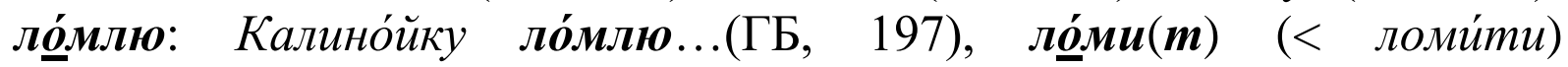
«заламувати руки» (ГБ, 54, 144), ломати, ло́мйе «ламати (кукуру́дзу)» (ДСсБ, 45), ламати, -мле «заламувати руки»: Ой втонула Василина, лиш хусточка плавле, ходит д’івча попри воду, білі руки ламле (despite the absence of accent markers in the illustration, the rhythmical pattern of the song distich, as well as the grammatical form of the verb analyzed, prove it belonging to the paradigm of Structural Class $\mathrm{V}$, and thus suffix-flexion accent. - K.І.) (СБГ, I, 402), lamáti, láml'u / lamáju, lámle / lámat, lamlí «ламати» (СКУТГ, 112), ламámu, ла́мл’y, ла́млеш «ламати»; «збирати врожай качанів кукурудзи» (Саб., 159).

The verbate under analysis in the variants of the literary language as well as in the modern Ukrainian language, despite its lexical-semantic derivation productiveness, represents only the grammatical paradigm of Structural Class III, though the illustrative material of the lexicographic source of the southeastern variant of the Ukrainian literary language represents it with Class V Presence which is characterized by suffix-root accent: лама́mи «ломити» (Пі, 122), лама́mи «ломити» (Жел., 397), лома́ти / ломи́ти, - собі голову (Жел., 412), лама́ти, -а́ю, -а́єщ «ламати, ломити, розламувати»; «підмивати (вода береги)»; «порушувати; не дотримуватися слова»: Не то ламле суботу, а ще й отием своїм зве Бога (Св. IV, 18) (Гр. II, $342-353)$, лама́тися, ма́юся, -сися «ламатися, розламуватися»: Все зараз ламмнеться $i$ гнеться (Ен. IV, 26); «заломлюватися (про промені)» (Гр. II, 353), лама́mu, -áю, -а́єш «згинаючи або б'ючи з силою, відділяти частини чого-небудь або розділяти щзось на частини»; «робити непридатним; руйнувати, псувати ударами»; «рімуче відкидати щэо-небудь 
традииійне, усталене; руйнувати, знищувати»; «умовляти когонебудь діяти певним чином»; «порушувати звичайний вигляд»; «викликати хворобливе відчуття ломоти» (СУМ, IV, 441).

Suffix accentuation of the designated verb belongs to accentuational acquirements of South Slavic languages, and root accentuation is a feature of West Slavic languages: лама́mи, [лома́mи], ломи́mи; - Russian лома́mь, ломи́mь, Byelorussian лама́ць, Old Rus. ламати, ломити; Polish tamać, tomić, Check lámat, lomit, Slovak lámat', lomat', Upper Sorbian tamać, lemić, Lower Sorbian tamaś, tomiś, Polabian lümĕt, Bulgarian ломи́, Macedonian ломи, Serbo-Croatian ло̀мити, Slovenian lomíti, Old Slavonic ломити; - Proto-Slavic lomíti, iterative lamati; related to Lithuanian lâmyti «ламати», lamiti «м'яти, гнути, ламати», lìmti «надломлюватися, ламатися»; Indo-European *lem- / lom«ламати; поламаний; м'який» (ЕСУМ, III, 1188).

In the dialects under investigation the Indo-European verbate стругати also proves grammatical and accent variance.

In Bukovynian and Upper Dniesterian subgroup of dialects the derivate represents the width of usage range (Hutsul, Upper Dniesterian, and Bukovynian dialects), lexical-semantic derivation productiveness, belonging to Structural Class III and suffix accentuation (at grammatical paradigm incompleteness): струха́mu «обчищзати від шкаралупи, лушпини (картоплю, кукурудзу)» (СГГ, 178), струга́ти, устружи́ко «тесати»; «чистити від лушпини овочі та фрукти» (СГГБ, 164), струга́ти «натирати (дев'ятьма намоченими плитками натиране укушене гадюкою місие)» (СГГР, 127), струга́ти, -га́є «знімати стружку; стругати (дерево)»; «знімати лушпиння; чистити (сиру картоплю)» (НРC, 247), струга́mu «знімати шкіру з овочів» (СБГГ, 528).

In the Galician variant of the Ukrainian literary language the verb analyzed proves its derivation nest productiveness (at grammatical paradigm incompleteness) and stem class suffix accentuation: cmpyzámu (Жел., 927), заструха́mu (Жел., 273), наструга́mu (Жел., 495), поструга́mu «стругати» (Жел., 719).

Among the Carpathian dialects it is present only in the local East Boyko subdialect, but with the variance of its grammatical paradigm and accent:

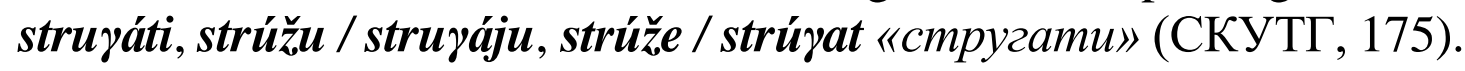

The designated verb manifests both lexical-semantic derivation productiveness and grammatical paradigm variance (with the same two accentuation types) in the southeastern variant of the literary language, and thus in the modern Ukrainian literary language: стругати «стругати» (Пі, 250), струга́mu, -га́ю, -сши і -жу́, -жеш «стругати»; «шкребти»: Стружсать глину (Вас.); «сильно дути (про вітер, завірюху)»: Ой по 
улиці та метіль струже (Гр. III, 324); «танцңювати»: Після сих другі стругали гусаря. (Мкр. Н, 30) (Гр. IV, 219); струга́ти, -ужсй, -ýжеш і -уга́ю, -уга́єш; нак. стружи́, стругай «знімати стружку з поверхні дерев, металу і т. ін.. яким-небудь різальним інструментом»: Ой йде милий дорогою та паличку струже, Ой як же я, мій миленький, люблю тебе дуже (Коломийка); «нарізати тонкими вузькими пластинками» // «знімати верхній шар з чого-небудь, робити його рівним, гладеньким»: Мати струже [припічок] та знов маже (Головко); «віяти з великою силою (про вітер, завірюху $i$ m. ін.)» (СУМ, IX, 788), струга́тися, стру́неться i струга́ється «піддаватися обробиі способом стругання» (СУМ, IX, 788).

The illustrative material of "Ethymological Dictionary of Ukrainian" in suffix accentuation of the verb analyzed proves accent acquirements of East Slavic languages, as in West and South Slavic languages it prevails with root accent type: струга́mu «знімати стружку; нарізати пластинками; сильно віяти», стругнутти, струг «ніж, яким чистять картоплю»; - Rus. строгámb, стругámb, Byelorussian стругáщь, Old Rus cmpугатu, стръгаmu, Polish strugać, Check strouhati «mерти на териі; стругати», Old sestrhal (koru) «зішкрябав», struhati, Slovak strúhat' «дрібно різати; застругувати», Upper Sorbian truhać «терти на тертиі; скребти; брити», Lower Sorbian tšugaś «mc.», Bulgarian стру́жа «обробляю на токарному верстаті», Macedonian струже «точить, струже», Serbo-Croatian стри́гати «точити; стругати», Slovanian stŕgati «скребти; терти на териті», «точити», Old Slavic стръгати (строугати) «шкребти, зикрябувати, здирати», стръгати са «бритися»; - Proto-Slavic strøgati «скребти, стругати»; Indo-European *streug-, derivative from *st(e)reu- «намазувати, гладити, робити смуги, торкатися» (ЕСУМ, V, 451).

In the supradialect under research the width of usage range (Hutsul, local Upper Dniesterian, Bykovynian, Boyko, Volyn subdialects), lexicalsemantic derivation productiveness (with the sporadicity of some sememes acquiring homonymic relations in Bukovynian and Boyko subdialects) is represented by one more Indo-European verbate of the former oxytonic accent paradigm, which unlike those analyzed above is characterized by only its belonging to the grammatical paradigm of Structural Class V and by the sequence of suffix-root accent: sukaty (sy) «сплітати, скручувати (свічки)», wsukájmo, ne zsuka, sukanyj (цнурок), sy súcziyt, Sukáty (nýtku, mótuz). Por. zasukaty (SH, 223); сукámu (ланьцухи́) «перебувати (в тюрмі)» (ГБ, 157), сука́ти", ссука́ти «виробляти калачі»: Я вже колачі́ ссука́ла... (СБГГ, 532); сука́ти², сучи́ «прати без мила»; «відіпрати (мурувати) в білизні забруднені місия» 
(СБГГ, 532); сука́mu «сварити когось» (СБГГ, 532); сука́mu, cýuy, су́ччеш «скручувати з кількох ниток в одну»; «намотувати нитку на шпульку для ткання полотна»; «терти, розбивати на дрібні шматки (про скло, кераміку)»; «лущити (теребити) качани кукурудзи» (Саб, 346), сука́тися, су́чиця «встрявати (в бійку)» (Корз., 232).

In Boyko subdialects it proves both belonging to Structural Class $\mathrm{V}$ and suffix-root accentuation, despite incomplete grammatical paradigm and variance accenting in the Infinitive (root, stem class suffix and the Infinitive suffix) in the western Boyko subdialects: cýкати, сука́mú, су́ккати нитки «крутити нитки»; «скручувати нитки»; сука́ти с'ві́тло «робити гноти для свічок; суикати ці́вочки «навивати иіівки на кросна» (СБГ, II, 265), sukáti, súču, -е «сукати» (СКУТГ, 176), сука́ти, сйчy, ср́чеш «скручувати, звиваючи кілька пасом, виготовляти щзо-небудь (налигач, мотузку і т. ін.); coarse «їсти (перев. багато)»: Той неро́ба нич не ро́бит, лиш су́че та й су́че, а коли насу́чеся - переве́рнеся, ки́мо, та й спит. (СГЦБ, 447).

In the lexicographic source of the Galician variant of the literary language the verbative defined is distinguished by both the productiveness of the morphological nest and stem class suffix accent (with traditional incompleteness of their grammatical paradigms): сука́mu, сукота́mu «скручувати» (Жел, 934), засука́mи / засуикувати «сука́ти» (Жел., 274), насука́ти / насу́кувати «сука́ти» (Жел., 496), посука́ти / посу́кнути (веретеном) (Жел., 720).

In the southeastern variant of the literary language the verb defined maybe by the analogy to those analysed above represents the same variance of Presence forms which belong to Structural Classes V and III, as well as variance (suffix and suffix-root) accentuation: сука́mu «сукати» (Пі, 251), сука́ти, -ка́ю, -єш / -чý, -чиш «сукати, зскручувати» (Гр. IV, 227). In the 11-volume "Dictionary of Ukrainian" the analyzed verbate is documented with its grammatical and accent variance, but the illustrative material is presented with only Presence forms

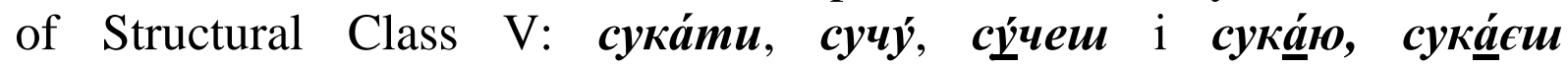
«скручувати, звивати кілька пасом разом»: Ті сучать аркани, ті гострять, Ті ружжя [гвинтівки] свої заряджають (Бор.). Сучить милі заметіль (Ус.); «перебирати руками, ногами» (СУМ, IX, 830).

Presence forms in South Slavic languages speak to root accent deriving from the oxytonic accent paradigm. Root accent in the Infinitive in West Slavic languages as well as in Slovenian and Serbian is motivated maybe by accent analogy to its Presence forms. The thematic affix accent (with the sporadicity of accentuating the finite affix in western Boyko subdialects) can be of the acquirements of the accent system of the 
Ukrainian, Russian and Byelorussian languages: сукámu, [сукámucя] «встрявати» (Корз.), [сукота́mu] «сукати» (Нед.), [сучи́mu] «the.», [сучи́тися] «нав'язуватися»; - Russian сука́ть, [скать] «сукати», сука́ць, сука́mь, др. съкати «тс.», Old Polish, Upper Sorbian sukać «сукати», Check soukati, skati, Slovak súkat', Lower Sorbian sukaś, Polabian sáuknö, Bulgarian cýкам, сйua, Macedonian сука, суче, SerboCroatian ḉ́кати, Slovenian súkati, Old Slavic сукно; - Proto-Slavic *śkati «в'язати вузли, зв'язувати, сукати, скручувати», sukati

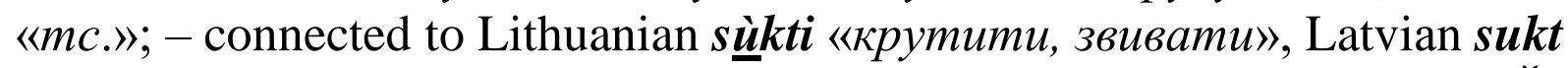
«mс.; зникати»; Indo-European ${ }^{*} \boldsymbol{s e u k}$-, derivative from $*_{\boldsymbol{s e u}}-$ / $\boldsymbol{s} \check{\overline{\boldsymbol{u}}}-$ «гнути, вертіти, підганяти», reflected in Old Indian suváti «приводити в рух» (ECYM, V, 470).

Thus, the verbs of Structural Class III of the former oxytonic accent paradigm in the southwestern dialects of the Ukrainian language, despite usage non-productiveness are characterized by lexical-semantic derivation productiveness (with the seme of grammatical redundance), grammatical paradigm variance (Presence forms belonging to Structural Classes III and $\mathrm{V}$ ) and accentuation variance (suffix-root and suffix). The former accent variant represents stressing the thematic affix in the Infinitive and the root in the Presence, which originates mainly from the oxytonic accent paradigm, correlating with accent features of West Slavic and rarer South Slavic languages. The latter (suffix) variant is of later acquirements of the accent system of the southwestern dialects, as well as of East Slavic languages (Ukrainian, Byelorussian and Russian).

\section{Phonetic-grammatical and accent correlation of verbs in the southwestern dialects of the Ukrainian language and South Slavic languages}

In the Carpatian (Boyko, Transcarpathian and Lemko) and rarer in the Bukovynian-Upper Dniesterian (Hutsul, Upper Dniesterian and Upper Sannyan) dialects Structural Class III and sporadically II verbs represent (mainly in singuar) presence paradigm variance.

The former of them is distinguished by preserving the relational affix $\left(-j^{-}\right)$and flexion vowels (with the root or the thematic affix stressed). The latter paradigm is characterized by their (flexion vowels) constriction “after having lost the intervocal $\boldsymbol{j}(\boldsymbol{a} \boldsymbol{\epsilon}>\boldsymbol{a})$ : припов'ídau, мáxau» ${ }^{10}$ (with the third person singular actualized) and the root morpheme stressed, irrespective of the accent type of the derivate. In Lemko subdialects the

10 Возний Т. М. Система дієслівних форм в говірці села Бітлі на Львівщині. Українська діалектна морфологія. Київ. 1969. Р. 178. 
verbs noted represent constriction in the majority of Presence forms and special flexions: $\boldsymbol{- \boldsymbol { M }}$ (1-st person sing. by the analogy to athematic verbs), $\boldsymbol{u}$ (2-nd person sing.), - $\boldsymbol{m}$ (3-rd person sing.), - $\boldsymbol{\boldsymbol { \mu }} \boldsymbol{e}$ (1-st person pl.), - $\boldsymbol{m} \boldsymbol{e}$ (2nd person pl.), $-\boldsymbol{y m}$ (3-rd person pl.).

The verbs of the first grammatical paradigm suffix type (with the flexion vowel constriction due to the intervocal relative affix reduction) were acquiring a different accent pattern, namely root accent in Presence forms singular, obviously by the analogy to accentuating root accent type verbs, rooted into the baritone accent paradigm. I. Pankevych analyzing accent peculiarities of Transcarpatian dialects hesitated on the motivation of the cause for "shifting the word accent to the initial syllable as it is in the Hungarian language or in Serbo-Croatian Stokavian dialects, today it is not easy to answer", though he was convinced that that this phenomenon "had its origin on the Slavic ground"11: поборыка́mu, -рь́кащu (-а́єш) «безладно порити землю» (Саб., 235); борона́ти, -на́йу, -ро́нащu (на́йеш) «боронувати» (Саб., 29); vertáti, vértat «повертати» (СКУТГ, 197), [vertáti]: -ju, vértat «вертати», (СКУТГ, 197); гачка́mu, -ка́йу, га́чкаш (-ка́йеш) «підкочувати штани собі або кому-небудь» (Саб., 46); розгортати, розго́ртам, -аㅆ «роздягати, скидати верхній одяг; розмотувати щуось загорнуте» (Пирт., 270); гуля́ти «гуляти» (ГБ, 232), but: гулє́ш (ГБ, 232); гусля́ти, л’а́йy, гу́cл'аш (л'а́йеш) «грати на скрипйі». Див. ще густи́.; «муркотати (про кота)»: гу́с'л'ат; гу́сл'ат (гусл'а́йе), перен. «хрипіти в грудях у старої або хворої людини» (Саб., 54); погаджуئл'ати, погаджсئл'ат (СБГ, II, 90);

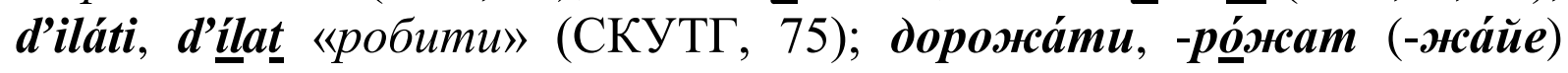
«дорожчати» (Саб., 73); dumáti, dúmat «думати» (СКУТГ, 79); [žadáti]: -ju, žádat «бажати» (СКУТГ, 214); зоря́mu [зо̂p’ámu], зốp’am (-р’айe) «світати» (Саб., 130); каля́ти [кал'ámu], л’а́йy, ка́л'аш (л'а́йеш) «забруднювати болотом, грязюкою, грязнити» (Саб., 138); karáti, kárat «карати» (СКУТГ, 98); [kasáti]: pri=kasáti $\boldsymbol{s}^{\prime} \boldsymbol{a}$, -ju s'a, pri=kásat s'a «доторкатися» (СКУТГ, 98); катуля́mu, кату́лям, -ящ «котити, пересувати круглий предмет у певному напрямі» (Пирт., 133), качуля́ти, качу́лят «котити» (Саб., 140), покачуля́ти, покачу́л'ащu «покотити» (Саб., 248); kusáti, -ju, kúsat «кусати» (СКУТГ, 110); лігámu, л’ízащ «лягати» (Саб., 162); льіта́mu (Верхр., 1900, 72), льіта́є, льị́mam (Верхр., 1900, 72); мина́ти «минати» (ГБ, 219), минаєщ «минати» (ГБ, 141); paláti,

${ }^{11}$ Панькевич I. Українські говори Підкарпатської Русі і сумежних областей. Прага. 1938. Part 1 P. 328. 
o=pálat «віяти зерно (трясучи в решеті)» (СКУТГ, 138), опала́mu, опа́лаш віяти зерно» (Саб., 214), опала́ти, -а́лам, -аш «підкидати хліб у формі перед його випіканням, формувати хлібину; очищати зерно від полови в коритці шляхом його підкидання на вітрі» (Пирт., 215); запріча́ти, -ча́йу, -р’і́чиш (-ча́йеш), запр’іча́ла «забороняти» (Саб., 107); пушчámu, nýu'u'am «пускати» (СБГ, II, 163), puščáti, puščáju, púščat «пускати; сплавляти (ліс)» (СКУТГ, 156), пуща́тии, -

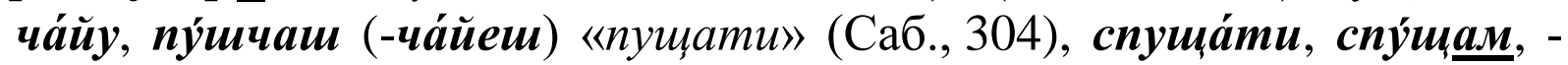
аш «спускати, опускати вниз» (Пирт., 290); rubáti, -ju, rúbat

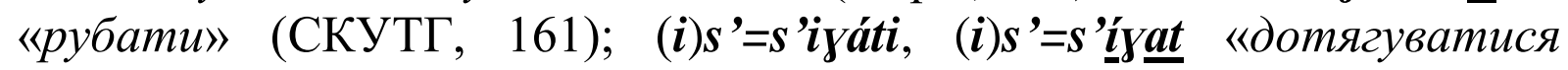
руками» (СКУТГ, 165); s’idáti, -ju, s'ídat «сідатu» (СКУТГ, 165); cmapámu, cmapam «добувати», «роздобувати» (СБГ, II, 249); stradáti, -ju, strádat «страждати» (СКУТГ, 174); талапати, тала́naü «важко йти по великій грязюиі або по чому-небудь грузькому» (Саб.,

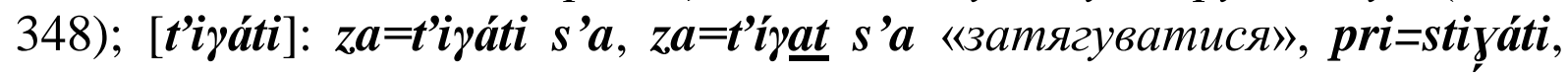
pri=stílat «причіпляти» (СКУТГ, 186), порозтігámu, поуроус'u’izau «порозтягати щчо-небудь пружне (гуму і под.) (Саб., 262); t’ir'áti «гнати», na=t'ir'áti, $\boldsymbol{n a}=\mathbf{t}$ ír'at «відганяти» (СКУТГ, 186); розтікатися, роิс'и'ікац':а «розливатися в різні боки» (Саб., 319); ховати, хо́вам, -аш «ховати, таїти щось» (Пирт., 328); с̌ekáti, čékat «чекати» (СКУТГ, 67); čẹr'áti, -ju, čér'at; čẹr'áj «черпати» (СКУТГ, 68); čítáti, -ju, čítat, -čítáj «чumamu» (СКУТГ, 70).

Prefix imperfectives have also undergone constriction of presence flexion vowels, and nowadays representing the connectedness of nonpreffix motivating derivates (at their being actualized in colloquial Russian) are distinguished by their semantic correlation with one-root prefix perfectives of the corresponding structural classes: обертати, $\boldsymbol{o}\left(\boldsymbol{o}^{y}, \boldsymbol{y}, \boldsymbol{в}\right)$ бе́ртаи «повернути» (Саб., 210); [beráti]: u=beráti, un=bírat

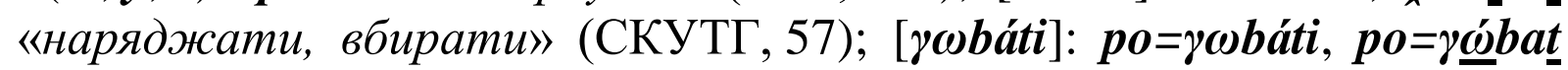
«nомирати» (СКУТГ, 91); [deráti]: po=za=deráju, po=za=dírat «дразнити» (СКУТГ, 74); [krašáti]: pri=krašáti, pri-kráśšá

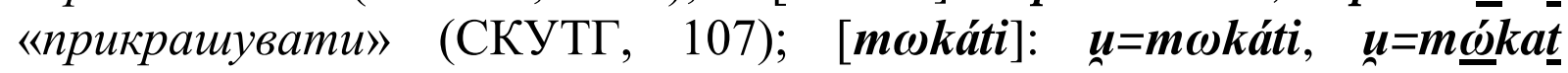

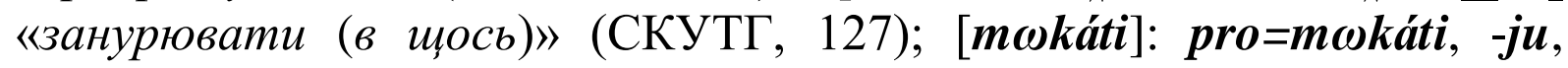
pro=mókat «ковтати, проковтувати» (СКУТГ, 127); перепікати, перепікат «пекти довше, ніж звичайно» (СБГ, II, 53); [pr'ijáti]:

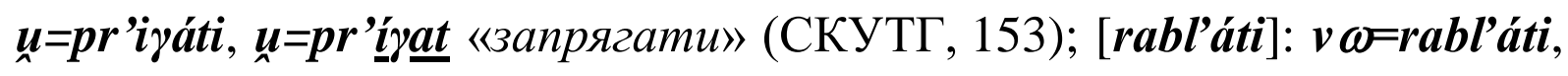
$v \omega=r \underline{a} b l ' a \underline{t}$ «виробляти» (СКУТГ, 156); r'ikáti: na=r'ikáti, -ju, na=r'íkat «жалітися на кого-н; давати ім'я дитині», za=r'ikáti s'a, -ju s'a, $z a=r$ 'ikat s'a «зарікатися» | un=r'ikáti «nіддавати пристріту», «зурочувати» (СКУТГ, 159); [staryáti]: po=staryáti s'a, po=stáryat s'a

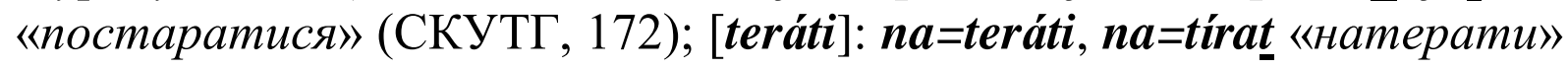




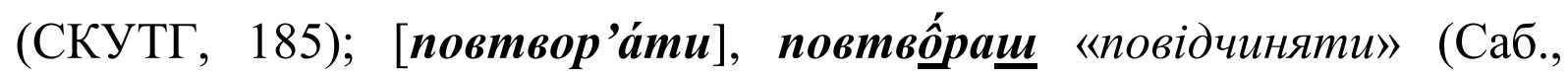
271); tináti]: un=tináti, u=tínat «наводити порчу на когось» (СКУТГ,

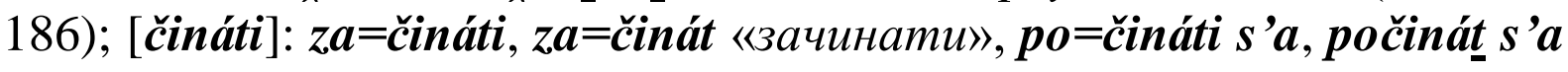
«починатися» (СКУТГ, 70).

In the Carpathian dialects with constricted presence flexions we come across a number of verbatives of the same root accent type structural class, rooted into the first baritone accent paradigm, which is motivated by phonetic-grammatical analogy to verbs with suffix accent type which derives from the second baritone accent paradigm: бizamu, бizam «бути в стані тічки» (СБГ, I, 54) (<*b'ěgati *b'ěgajetb (1-st a.p.а.) (Скл., 346), побігати, побі́zaщu «побігати»; -ам «стати тільною (про корову» (Саб., 24); bróskati, bróskat_«бризкати, пирскати» (СКУТГ, 63); вішатися, c'a вímат «вішатися»; «пустувати (переважно про

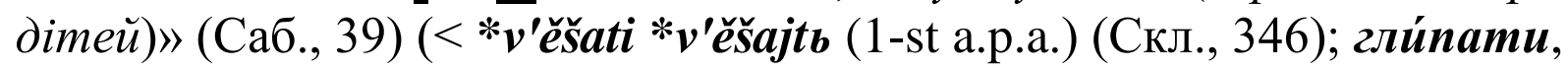
гли́паш «поглядати»; «поглядувати кудись, оглядатися» (Саб., 48); го́йкати, го́йкат «кричати, гукати»; «кричати «гой»; «лаяти, сварити» (СБГ, I, 179); дрáшпати, дрáuпаш «дряпати» (Саб., 78); дужати, дужащи «міиніти» (Саб., 80); кло́пати, кло́паш «стукати в двері, просячи дозволу увійти» (Саб., 144); ку́шати, ку́шаш «пробувати, куштувати їжу» (Саб., 158); ль́ьгати, ль́́ гаш «хитати; рухати (лавицею)» (Саб., 161); попа́хати, попа́хаш «понюхати» (Саб., 258); попаха́mu, попáxaм, -ащu «понюхати» (Пирт., 244); пь́рхати, пь́рхаш «літати, пурхати» (Саб., 230); ца́бати, -аю, -аш (-аєш) «лазити навколішки, пересуватися в горизонтальному положенні» (Саб., 406); шпо́тати «підкладати ногу людині, щзоб спіткнулася» (СГЦБ, 527), шпо́тати, -аю, -аш (-аєш) «робити підніжку» (Саб., 424), шпо́ртати, шпо́ртам, - $\underline{\text { ащ } ~ « ш п о р т а т и, ~}$ колупати» (Пирт., 352).

Presence flexions constriction has also happened to the verbs which in different dialects of the southwestern supradialect are distinguished by accentuation variance: гл'ádamu, гл'ádau «шукати» (Саб., 49); ob=ziráti s'a, ob=zírat s'a «оглядувати» (СКУТГ); обзера́mu, -е́pa. ащи «оглядати, приглядатися до чогось» (Пирт., 204); полупа́ти, полу́пащ «поколупати» (Саб., 252); попь́mamu, попь́maш

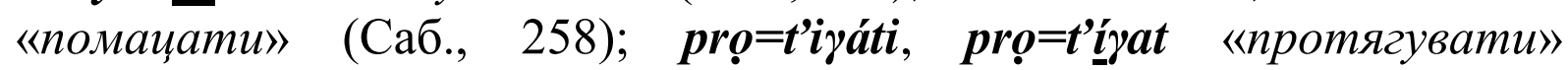
(СКУТГ, 186); похра́матися «почати шкутильгати, захворіти на ноги» (СБГ, II, 128), хра́мати «шкандибати, маючи укорочену або хвору ногу; кульгати» (СГЦБ, 499), хра́мати «кульгати» (НРС, 268), хро́мати «кульгати» (ДСсБ, 92), хра́мати «кульгати, икутильгати»; «допускати життєві помилки» (СГГБ, 178), хра́áámu «шкутильгати» (СБГГ, 615), хра́мати (Жел, 1045), 
хра́ммати,-аю, -аш (-асш) «кульгати, шкандибати» (Саб., 405), похра́ммати, похра́́маш «покульгати, пошкандибати» (Саб., 273).

It is interesting that verbs with loan roots (with root stress predominating in the source language) also represent presence flexion constriction caused by the same analogy: пога́ŭdamu, noráŭdau «попатякати»(Саб., 239); тматва́тии(ся), тма́твам(ся), -аш(ся) «плутати (ся), заплутувати(ся)» (Пирт., 69); капча́ти, ка́nчаш «застібати»; «з'єднувати», Cf. Hungarian kapcsa «клямба» (Саб., 138); попла́mаш (попла́тати) «полатати». Сf. пла́тати (Саб., 259); шпо́mати, -айу, -аш (-айеш) «робити підніжку»; «заважати кому-небудь у чомусь». Cf. German spotten «насміхатися, знущцатися» (Саб., 424).

\section{CONCLUSIONS}

Thus, vowels constriction in presence flexions of the first, second and third person singular (rare) and root morpheme accent is a characteristic phonetic and accentuation feature of the verbs (mostly of Structural Class III with suffix accent type) of southwestern dialects of the Ukrainian language, the Carpathian subgroup in particular, which correlates them with phonetic and accentuation peculiarities of the Bulgarian, Serbian, Croatian and Polish languages ${ }^{12}$. In Lemko subdialects flexion constriction is characteristic of also other grammatical forms of the verbs analysed. The actualisation of the defined processes in autochthonous derivates of western Boyko, local modern eastern Boyko, Transcarpathian and Lemko subdialects caused their spreading onto verbates with loan roots.

Presence forms representing the specifics of phonetical and accentuation processes of the southwestern dialects have not become an acquirement of the Galician variant of the Ukrainian literary language, as in the analysed lexicographic source the analysed verbs are represented mostly in the form of the Infinitive. They have not contributed to grammatical system of the southeastern variant of the Ukrainian literary language, and thus to the modern Ukrainian literary language either.

\section{SUMMARY}

In the article accent processes of Structural Class III suffixal accent type verbs in the southwestern dialects of the Ukrainian language with their lexical-semantic, semantic-grammatical, derivational, phonetic and

12 Онишкеич М. Бойківсько-південнослов'янські мовні паралелі. Праці ХІІ республіканської діалектологічної наради. Київ. 1971. Р. 443. 
etymological peculiarities correlation have been analyzed. Accentuation analysis of the designated verbs has been conducted by contrasting their accentuation features in the variants of the literary language, the modern Ukrainian literary language and other Slavic languages. It has been detected that most of the defined class's verbs (except the derivates of sound or interjection semantics) are characterized by accent uniformity (accenting stem class suffix throughout the whole grammatical paradigm). Among the derivates of the structural class under investigation a big group of prefixal derivates which in the Ukrainian language are characterized by stem connectedness (with their actuality in Russian), by the imperfectivity of the suffix accent correlative grammeme, and by the ability of correlating with one-root prefixed perfectives of different structural classes have been noted.

Of accent specifics are rooted into late Proto-Slavic oxytonic accent paradigm verbs. They represent grammatical (belonging to Presence forms of Structural Classes V and III) and thus accent (suffix-root and suffix) variance. Suffix-root accentuation being characteristic of the grammatical paradigm of Structural Class V verbs correlates with accent features of West Slavic and rarer of South Slavic languages. Suffix accent type being characteristic of Structural Class III derivates is of later accent acquirements of the southwestern dialects and East Slavic languages.

Lingual peculiarity of the southwestern supradialect, esp. of the Carpathian dialect subgroup, is the availability of a considerable number of Structural Class III and rarer II verbs which are characterized by phonetic and accent variance.

Forms with accented thematic affix in the Infinitive and root in the Presence correlate with accent peculiarities of verbates in South Slavic languages, and affix accent throughout the whole grammatical paradigm correlate them with the southeastern variant of the Ukrainian language as well as the modern Ukrainian, Byelorussian and Russian languages.

\section{REFERENCES}

1. Гриценко П.Е. Феномен диалектного явления: онтология и гносеология. Исследования по славянской диалектологии: Судьба славянских диалектов и перспективы славянской диалектологии в ХХІ веке. Москва. 2015. Вып. 17. Ст. 9 - 59.

2. Винницький В. Українська акцентна система: становлення, розвиток. Львів. 2002. 578 с.

3. Попова Т. В. «Восточнословянские изоглоссы» и проблема дифференциации восточнославянского диалектного континуума. Исследования по славянской диалектологии. Восточнославянская 
диалектология, лингогеография и славянский контекст. М. 2002. № 8. Ст. $18-25$.

4. Огієнко I. Наголос, яко метод означення місця наголосу стародрукованих книжок. Замітки 3 історії наголосу на послугах палеотипії. Записки НТШ. Праџі фільольогічної секиії. Львів, 1925. T.T. CXXXVI-CXXXVII. Ст. 197 - 224.

5. Ковалик I. I. Граматична структура системи дієслівних форм у сучасній українській літературній мові. Питання українського $i$ слов'янського мовознавства. Вибрані праці. 495с. Львів - ІваноФранківськ. 2008. Ч. II. Ст. $143-149$.

6. Іваночко К. Акцентуація фауноономатопоетичних дієслівних дериватів у південно-західних говорах української мови. Лінгвістика. Збірник наукових працъ. Луганськ. 2012. Випуск 2 (26). Ст. 71 - 88.

7. Іваночко К. Акцентуація ономатопоетичних ентомологічних суфіксальних дієслівних утворень у південно-західних говорах української мови. Вісник Львівського університету. Філологія. Львів. 2012. Випуск 57. Ст. 263 - 274.

8. Іваночко К. М. Наголосова варіантність предметних ономатопів третього структурного класу в південно-західних говорах української мови. Науковий вісник Міжнародного гуманітарного університету. Серія: Філологія. Збірник наукових праць. Одеса. 2017. Випуск 28. Ст. $15-20$.

9. Скляренко В. Г. Історія українського наголосу. Дієслово. Київ. 2016. 702 с.

10. Закревська Я. В. Система особових форм дієслова в західних говорах української мови (Теперішній час). Украӥнська лінгвістична географія. Київ. 1966. Ст. $132-139$.

11. Возний Т. М. Система дієслівних форм в говірці села Бітлі на Львівщині. Українська діалектна морфологія. Київ. 1969. Ст. $177-183$.

12. Панькевич I. Українські говори Підкарпатської Русі i сумежних областей. Прага. 1938. Ч. 1. 549 с.

13. Онишкевич М. Й. Бойківсько-південнослов'янські мовні паралелі. Праці ХІІ республіканської діалектологічної наради. Київ. 1971. Ст. $440-446$.

\section{LEGEND}

1. Б.-Н. - Білецький-Носенко П. Словник української мови. Київ. 1966. 421 с.

2. Верхр., 1900 - Верхратський I. Про говір долівський. Зап. Наук. m-ва ім. Т. Шевченка. Л. 1900. Т. 35 - 36. Кн. 3 - 4. С. 1 - 128. 
3. ГБ - Верхратський І. Говір батюків. Львів. 1912. 308 с.

4. Гов. - Говори української мови (збірник текстів). Київ. 1977. $590 \mathrm{c}$.

5. Гр. - Словарь української мови: у 4-х томах. Київ. 1958. Т. II. 1959. T. III, IV.

6. ДСсБ-Горбач О. Діялектний словник села Бродина повіту Радівці (Румунія). Південнобуковинська гуцульська говірка і діялектний словник села Бродина повіту Радівиі (Румунія): Матеріали до украӥнської діалектології. Випуск 4. Мюнхен. 1977. 102 с.

7. ДСсР - Горбач О. Словник діалектної лексики північнонаддністрянської говірки сіл Романів, Підсоснів, Підберізці й Лагодів. Північно-наддністрянська говірка й діялектний словник с. Романів Львівської области. Мюнхен. Т. VII (X). 1965. С. 24 - 103.

8. ЕСУМ - Етимологічний словник української мови: у 7-и т. Київ. 1982 - 2012. T.T. 1989. T. III. 549 c.; 2003. T. IV. 652 c. 2006. T. V. $703 \mathrm{c}$.

9. ЭССЯ - Этимологический словарь славянских языков. Праславянский лексический фонд. Москва. 1984. Выпуск 11. 220 с.

10. Жел. - Желеховський $\mathrm{C}$., Недільський С. Малоруско-німецкий словар: У 2 т. Мюнхен. 1886. ТT. I - II. - 1117 с.

11. МСГГ - Піпаш Ю. О. Матеріали до Словника гуцульських говірок. Ужгород. 2005. $264 \mathrm{c.}$

12. НРС - Шило Г. Наддністрянський регіональний словник. Львів. 2008. 288 с.

13. Пирт. - Пиртей П. Короткий словник лемківських говірок. Івано - Франківськ. 364 с.

14. Пі - Словник живої народнеі, письменної і актової мови руськихъ югівщанъ Російськоі і Австро-Венгерськоі цесарії. Кіевъ. 1882.304 с.

15. Погр. - Погрібний М. Словник наголосів. Київ. 1964. 639 с.

16. Саб. - Сабодаш I. Словник закарпатської говірки села Сокирниця Хустського району. Ужгород. 2008. 478 с.

17. СБГ - Онишкевич М. Й. Словник бойківських говірок : У 2-х ч. Київ. 1984. Ч. І. 495 с.; Ч. II. 515 с.

18. СБГГ - Словник буковинських говірок. Чернівці.2005. 688 с.

19. СГГ - Гуцульські говірки. Короткий словник. Львів. 1997. 232 с.

20. СГГБ - Негрич М. Скарби гуцульського говору: Березови. Львів. 2008. 224 с.

21. СГГР - Грицак М. Скарби гуцульського говору: Росішка. Львів. 2008. 318 с. 
22. СГЦБ - Матіїв М. Словник говірок центральної Бойківщини. Київ - Севастополь. 2013. 601 с.

23. Скл. - Скляренко В. Г. Історія українського наголосу. Дієслово. Київ. 2016. 702 с.

24. СКУТГ-Словарь карпатоукраинского торуньского говора. Москва. 2001. 216 с.

25. СУМ - Словник української мови : в 11-ти т. Київ Наукова думка. 1973. Т. IV. 840 с.; 1978. T. IX. 916 с.

26. УГР - Павлюк М., Робчук І. Українські говори Румунії: діалектні тексти. Едмонтон - Львів - Нью-Йорк - Торонто. 2003. 782 с.

27. УЛВН - Українська літературна вимова і наголос. Київ. 1973. $724 \mathrm{c}$.

28. SH - Janów J. Słownik huculski [text]. Krakow. 2001. 302 s.

\section{Information about the author:} Ivanochko K. M., Candidate of Philology, Associate Professor at the Department of Ukrainian Language, Drogobych State Pedagogical Ivan Franko University 16/3, A. Sheptytskyj str., Drogobich, 82104, Ukraine 